\title{
Beyond payments for ecosystem services: considerations of trust, livelihoods and tenure security in community-based conservation projects
}

\author{
Alicia Davis and Mara J. Goldman
}

\begin{abstract}
In the search for successful community-based conservation models there has been a substantial focus on payment for ecosystem services. Such payments are measurable inputs that are often associated with conservation success. A closer look suggests a more complex, historically and culturally contingent picture. We argue that a focus on payment for ecosystem services as a defining factor for success in community conservation risks overlooking other, more significant processes. In particular, we argue for the importance of (1) tenure and livelihood security and (2) relations of trust, communication and respect. We draw on case studies from East Africa, but the findings are relevant for global community-based conservation endeavours.
\end{abstract}

Keywords Community conservation, East Africa, Kenya, pastoralism, payment for ecosystem services, PES, Tanzania, wildlife conservation

\section{Introduction}

$\mathrm{T}$ here has been much debate on the potential and limitations of payment for ecosystem services for successful community-based conservation (Millennium Ecosystem Assessment, 2005; Muradian et al., 2013; Agarwala et al., 2014; Schröter et al., 2014). Although the approach has been heavily criticized, it continues to be promoted not only as an efficient way to address environmental governance concerns and climate mitigation needs (NaughtonTreves \& Wendland, 2014) but also as the essential factor for successful biodiversity conservation in community lands (Nelson et al., 2010; Naidoo et al., 2011). We argue that this primary focus on payment for ecosystem services risks leaving other factors unexamined and ignores broader processes that contribute to the success or failure of conservation interventions in community lands. In particular, we argue for the importance of community tenure and livelihood security, communication, and trust, which facilitate direct community involvement in conservation governance.

Alicia Davis School of Geographical and Earth Sciences, University of Glasgow, UK

Mara J. Goldman (Corresponding author) Department of Geography and Institute for Behavioral Science, University of Colorado-Boulder. 260 UCB, Boulder, Colorado 80309-0260, 303.492.8794.E-mail mara.goldman@colorado.edu

Received 12 January 2017. Revision requested 24 March 2017.

Accepted 26 May 2017. First published online 15 August 2017.
Our work draws from and contributes to a growing literature suggesting conservation success depends on the support of local communities (Hulme \& Murphree, 2001; Agarwala et al., 2014; Oldekop et al., 2016). Such support cannot be secured by payments alone but is tied to effective community participation and representation (Dyer et al., 2014), support of local institutions and cultural context (Waylen et al., 2010; Goldman \& Milliary, 2014), equitable distribution of benefits (Pascual et al., 2014), two-way flows of knowledge, and flexibility in decision-making processes (Hayes et al., 2015; Reid et al., 2016; Wegner, 2016). Here we illustrate how community support of conservation is also connected to (1) community tenure and livelihood needs, and (2) relations of trust and mutual respect. We do this by comparing three approaches to wildlife conservation in pastoral rangelands in East Africa: two payment for ecosystem services projects that successfully secured community support, and one project that did not involve payment for ecosystem services and was actively opposed by communities. On the surface this may suggest payment for ecosystem services engenders conservation success. Yet a close comparative look at all of the cases highlights the importance of other factors.

\section{Background}

Payment for ecosystem services is broadly defined as a 'voluntary, conditional transaction between at least one buyer and one seller of a well-defined service (or corresponding land-use proxy)' (Wunder, 2013, p. 203). Financial payments are linked with conservation-based conditionalities, often through centralized, inflexible contracts (Hayes et al., 2015). Although the approach has been criticized for being market-based, others point out that not all payments are tied to markets and that payment for ecosystem services can incorporate multiple measurements, including nonmonetary values (Abson \& Termansen, 2011; Milcu et al., 2013; Shapiro-Garza, 2013; Turnhout et al., 2013). Payments linked to the condition of keeping land undeveloped can assure transactions between partners yet remain untied to market fluctuations and may help communities avoid poverty-environment traps (Lawlor et al., 2013). Land tenure and community control over resource management has been recognized as a necessary prerequisite for the success of a payment for ecosystem services project, to ensure that service providers (communities, land-owners) are 
accountable, and land-use restrictions and conservation measures are enforceable. It is often assumed that payment for ecosystem services is unlikely to work if alternative land uses with higher economic incentives exist, as so-called rational actors will choose the most economically advantageous option. Yet this presumes that all land-use decisions are made according to economic motivations, which draws on a rational choice understanding of social institutions (Van Hecken et al., 2015), but, as we show below, this is not always the case.

There is increasing recognition of the need for payment for ecosystem services schemes in community lands to address the complex bundle of community needs in order to succeed, including land tenure security, well-being of people and livestock, institutional support, and food and livelihood security (Sommerville et al., 2010; Lawlor et al., 2013; Agarwala et al., 2014; Salerno et al., 2016). Van Hecken et al. (2015) suggest the need to move beyond the fetishism of payments, to understand environmental governance institutions as complex and contested political arenas. We agree with these assessments but seek to move the discussion further still. Rather than asking what factors are associated with the success or failure of payment for ecosystem services schemes, we look beyond the payment mechanism towards other factors that may be driving success or failure of a conservation project, whether or not it involves payment for ecosystem services. We argue for a focus on non-economic values attached to various land-use options by community members, such as land tenure and livelihood security. This is particularly important in areas where communally managed land is essential for livelihood survival, but tenure security and access to such lands is not assured, such as in the pastoral-dominated savannah ecosystems in East Africa. In such cases, market rationale may dictate more profitable land uses, but payment for ecosystem services schemes may facilitate conservation initiatives if they help secure community tenure and the availability of grazing land for both livestock and wildlife.

\section{Conservation in East African savannahs}

East African savannahs highlight a set of particular, although not unique, conservation challenges: landscape fragmentation impinging on wildlife and livestock migratory patterns (Galvin et al., 2006), and local distrust of conservation interventions as a result of histories of land loss, deception and forced evictions (Igoe, 2000; Brockington, 2002). In these ecosystems, conservation success depends on protecting land for both wildlife and livestock. Securing community support for conservation is linked directly to, among other factors, (1) securing community land tenure rights and livelihood capacities (i.e. pastoralism), and (2) building relationships with communities, based on trust, open communication and respect. We draw from qualitative data and published accounts to explore three conservation interventions in Maasai-dominated rangelands: (1) an unsuccessful conservation trust in Tanzania, (2) a successful community conservation easement in Tanzania, and (3) a successful conservation lease programme in Kenya (Fig. 1).

\section{Manyara Ranch: a community-based conservation trust}

Manyara Ranch is a 17,807 ha conservation land trust situated in an area deemed to be an essential wildlife corridor between Lake Manyara and Tarangire National Parks in Tanzania (Goldman, 2009). It is also an important drought reserve for local pastoralists. During the colonial period a white rancher requested access to the land and, as its use by the Maasai was irregular, elders agreed. Following independence, the area became a state-run cattle ranch. In the 199os the land was offered for sale and the two villages claiming original ownership formally requested it be returned to them. The communities planned to use the area for dry-season grazing, and to work with the African Wildlife Foundation on wildlife conservation tourism. Through a series of non-transparent negotiations, village leaders were deceived into thinking they had secured the land, but a 99-year lease was instead granted to the Tanzanian Land Conservation Trust (TLCT, 2002). Village residents were unaware that they had lost land ownership rights, until the Trust began managing the area contrary to their wishes. To alleviate fears, the Trust hired a community liaison officer; however, he was from outside the area, from a rival tribe, and community members mistrusted him.

Since 2004 the African Wildlife Foundation has used Manyara Ranch as an icon of the success of the land-trust model for conservation (Sachedina, 2008). They claim that wildlife numbers have increased and villages have benefited economically through employment as game scouts, livestock development projects, and fees from a foreign-owned safari lodge. However, community resentment and distrust threatened the success of Manyara Ranch from the outset (Goldman, 2011). Local people claimed their participation in decision making was limited, their knowledge disrespected and their livelihoods threatened, as crop-raiding by wildlife increased on their farms and their access to grazing inside the ranch was restricted, even during drought (Goldman \& Riosmena, 2013).

Antagonistic relations between local people and the Trust led to illegal grazing and pasture burning inside Manyara Ranch and increased lion hunting throughout the area. Residents perceived the area as belonging to the African Wildlife Foundation, and felt they had no control, no voice, and little incentive to respect the Ranch's conservation status. In 2003 the African Wildlife Foundation introduced a payment for ecosystem services scheme to pay 
local people to effectively lease their farms for conservation, but people rejected it because of bad relations with the organization. When interviewed about the potential for refraining from farming, and from hunting lions that preyed on livestock, in exchange for payments from Manyara Ranch, people explained that money would not solve the problem. They needed access to pastures inside the Ranch, and to trust that management would work with them to alleviate human-wildlife conflict and not take more of their land. The people continued to campaign for control over the land, and in December 2016 the prime minister transferred the title to the original villages. Although the future of Manyara Ranch is uncertain, there is overwhelming interest from communities in maintaining its conservation focus, under village control.

\section{The Simanjiro Grazing and Conservation Easement}

The Simanjiro Grazing and Conservation Easement covers c. $300 \mathrm{~km}^{2}$ of village lands on the Simanjiro plains, east of Tarangire National Park. Wildlife migrate beyond the Park to the Simanjiro plains every rainy season for higherquality pasture. These grasslands are critical for calving wildebeest and Maasai livestock herds (Kahurananga \& Sikiluwasha, 1997). Residents and conservationists alike perceive the plains to be threatened by increased agricultural production, poaching, and land acquisition by outsiders (Igoe, 2004; Msoffe et al., 2011). Numerous conservation efforts have been undertaken, with various levels of success (Sachedina, 2008; Davis, 2011). The Easement, touted as exemplifying the success of payment for ecosystem services (Sachedina \& Nelson, 2010; Ingram et al., 2014), is based on a model in which villages are compensated directly with a yearly payment to keep the plains open for livestock and wildlife grazing but closed to settlement and farming.

The Easement was born from grassroots efforts between local people, a local indigenous-rights NGO, a tour company known for community-based tourism, and the Wildlife Conservation Society (WCS). The project was founded on residents' desire to protect wet-season pastures for livestock grazing under increased pressure to divide and privatize village land. The Easement applies Maasai landmanagement techniques, with a board of customary leaders coordinating grazing in easement land. WCS hires game scouts on rotation from the village, fostering a sense of ownership and pride. The village assembly decides how annual fees are spent. At annual village meetings, partners emphasize village ownership of and control over the land. The local NGO is helping villages acquire Certificates of Customary Rights of Occupancy, which secure village land titles through formalized land-use planning. A member of the local NGO is a long-term resident of the area and serves as community liaison officer.
The Nature Conservancy now supports the Easement and the broader work of the local NGO to facilitate village land tenure throughout Simanjiro. Residents are satisfied and additional villages have requested to join the project. People are happiest with the benefits to their livestock and control over their pasture. Local cattle fetch higher market prices during the dry season because they are well fed. Residents feel a sense of ownership of the project, even initiating a court injunction against another village's encroaching farmlands. In addition to providing funds, the Easement is building community capacity to secure land tenure and maintain control over communal pastures.

\section{The Kitengela Conservation Lease Agreement}

Kitengela was historically a Maasai township adjacent to Nairobi National Park, in Kenya. It comprises c. $390 \mathrm{~km}^{2}$ of the larger Athi-Kaputiei savannah ecosystem $\left(2,456 \mathrm{~km}^{2}\right.$, of which the Park covers only $114 \mathrm{~km}^{2}$ ) (Nkedianye et al., 2009). Subdivision of communal land in the 1980 os and land sales in the 199os increased urban and peri-urban development, the expansion of flower farms, and in-migration of non-Maasai landowners and farmers. This has led to increased fragmentation of grazing lands, threatening to close off migratory routes of wildlife from the Park and limiting livestock grazing access (Reid et al., 2008).

The Wildlife Conservation Lease Program was initiated in 2000 by Friends of Nairobi National Park, and later taken over by The Wildlife Foundation (Kenya Wildlife Service et al., 2006). The project utilizes payment for ecosystem services to prevent further fragmentation of pastureland in a wildlife dispersal area. Private landowners are paid KSH 300 per acre per year (USD 4.25 in 2006) to support wildlife on their land by keeping land intact and unfenced, refraining from poaching, and protecting vegetation. From the start, the project was collaborative and communitybased. The International Livestock Research Institute conducted participatory research with community members to map the location of fences, and hired a local liaison officer to share community needs and knowledge with the Institute and The Wildlife Foundation (Reid et al., 2016).

The project has been successful: it expanded from 11 participants leasing several hundred acres in 2000 to 117 families leasing 8,545 acres $(3,458 \mathrm{ha}$ ) in 2003 (Nkedianye et al., 2009). By 2012, 417 families were participating, covering $>61,067$ acres $(>24,713$ ha) (Matiko, 2014). Payments are made several times per year to correspond with school payment deadlines. Project participants send their children to school, have improved attitudes towards wildlife, and are more interested in keeping pasture open than those not involved (Nkedianye et al., 2009). Most importantly, where land is in such high demand, participants claim the scheme allows them to choose not to sell, by reducing the pressure to 


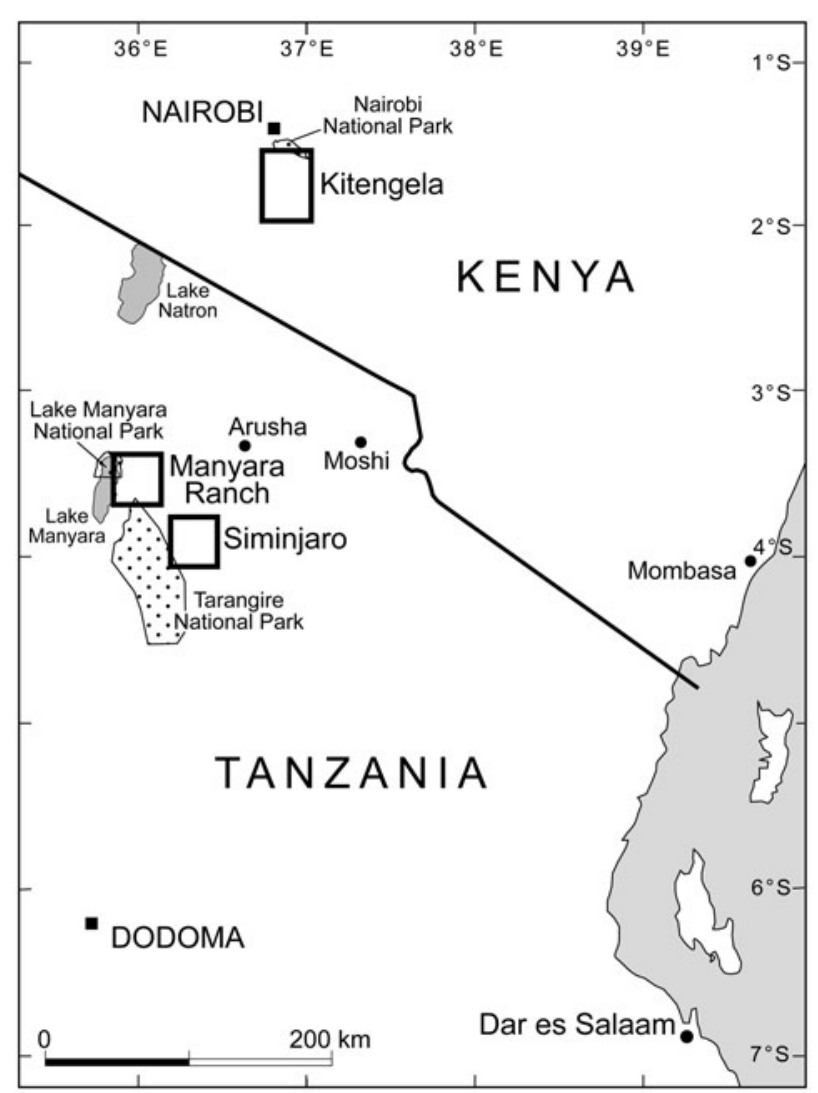

FIG. 1 Location of the study areas in Kenya and Tanzania.

obtain school fees (ibid.). In Kitengela, land sales are related to poverty (school and household needs) and wealth (investing in a growing land market). Those who do not sell often fence their land ( $60 \%$ in a 2004 household survey) to reduce wildlife conflict (ibid.). The lease payments provide financial support to keep land from being fenced or sold. Community members are also hired to intervene in incidents of predation by lions, to reduce human-wildlife conflict. Homeowners have recreated the commons by not erecting (and sometimes removing) fences, making Kitengela a more attractive place for livestock and wildlife.

\section{Discussion}

The two successful cases presented above, in terms of gaining and maintaining community support and increasing conservation coverage, utilized payment for ecosystem services. This would suggest that payment for ecosystem services is key to successful community conservation. Yet we argue that the cases illustrate otherwise. In both Simanjiro and Kitengela, conservation efforts were collaborative, built on open communication, trust and respect with community members, and worked to secure land for pastoralists and wildlife (e.g. tenure). We argue that these elements are key to the success of any community-based conservation project, whether or not it involves payment for ecosystem services. In contrast, in the case of the Manyara Ranch, distrust and deception prevailed, community participation was limited, and land ownership was in the hands of the conservation organization, which prioritized wildlife over livestock. Furthermore, antagonistic relations with Manyara Ranch resulted in community refusals to participate in a proposed payment for ecosystem services project, suggesting that payments are insufficient incentives for community engagement with conservation. The inclusion of payments facilitated both the Simanjiro and Kitengela projects, but conservation incentives were founded on land tenure security and grazing access, and accepted because of trusted relationships.

Land tenure is often discussed as facilitating payment for ecosystem services schemes. We argue that a payment for ecosystem services project becomes attractive to communities if it can facilitate land tenure security. The successful cases provided land tenure, livelihood security, and wildlife conservation by facilitating community control of pastures and enabling people (with small payments) to opt out of converting/selling pastures. Although the money received may be less than the amount that could be made selling land, keeping the land available for livestock (and hence wildlife) grazing was perceived to be more valuable.

Our findings reflect a growing recognition of the need to consider non-monetary environmental values to bring about behavioural change in conservation projects, whether or not they involve payment for ecosystem services (Kosoy \& Corbera, 2010; Fisher, 2012; Gross-Camp et al., 2012; Van Hecken et al., 2015). These include socio-cultural values such as protecting traditional customs, institutions and livelihoods, and the importance of trust and communication, particularly with outside groups (Horowitz, 2010). Building trust with local communities through open, respectful communication and participation should be the foundation on which conservation programmes are built, as should an appreciation of how existing livelihoods can be supported to simultaneously support conservation. Both successful cases discussed here hired Maasai liaison officers from the communities at the outset to participate in research and early planning and to bridge conservation and community needs. Manyara Ranch hired a (non-local) liaison officer after the fact, to ease tensions resulting from conservation-imposed land-use restrictions. Communitybased conservation often begins with the assumption that communities need to be convinced to respect nature, through payments and education. Our cases illustrate that payment for ecosystem services can facilitate existing desires within communities to support their own livelihoods that align with conservation goals. This may not always be the case, but through open communication and respect, compromise is more likely. This, we suggest, is a more solid starting point, than the focus on monetary value, to incentivize conservation. 


\section{Acknowledgements}

This research was supported in part by the National Science Foundation (\#0602034 and \#0921507). We thank the Tanzanian Commission for Science and Technology and residents of Terrat, Kitengela, Oltukai and Esilalei villages. Fig. 1 was produced by Mike Shand, University of Glasgow. The authors alone are responsible for all opinions and omissions.

\section{Author contributions}

The authors made comparable contributions to the paper. MJG contributed the Kitengela section and provided the lead on the Manyara Ranch section. AD led the Simanjiro section.

\section{References}

Abson, D.J. \& Termansen, M. (2011) Valuing ecosystem services in terms of ecological risks and returns. Conservation Biology, 25, 250-258.

Agarwala, M., Atkinson, G., Palmer Fry, B., Homewood, K., Mourato, S., Rowcliffe, J.M. et al. (2014) Assessing the relationship between human well-being and ecosystem services: a review of frameworks. Conservation \& Society, 12, 437-449.

Brockington, D. (2002) Fortress Conservation: The Preservation of the Mkomazi Game Reserve, Tanzania. Indiana University Press, Bloomington, USA.

Davis, A. (2011) 'Ha! What is the benefit of living next to the park?' Factors limiting in-migration next to Tarangire National Park, Tanzania. Conservation \& Society, 9, 25-34.

Dyer, J., Stringer, L.C., Dougill, A.J., Leventon, J., Nshimbi, M., Chama, F. et al. (2014) Assessing participatory practices in community-based natural resource management: experiences in community engagement from southern Africa. Journal of Environmental Management, 137, 137-145.

Fisher, J. (2012) No pay, no care? A case study exploring motivations for participation in payments for ecosystem services in Uganda. Oryx, 46, 45-54.

Galvin, K.A., Reid, R.S., Behnke, JR, R.H. \& Hobbs, N.T. (2006) Fragmentation in Semi-Arid and Arid Landscapes: Consequences for Human and Natural Systems. Springer, Dordrecht, The Netherlands.

Goldman, M. (2009) Constructing connectivity: conservation corridors and conservation politics in East African Rangelands. Annals of the Association of American Geographers, 99, 335-359.

Goldman, M.J. (2011) Strangers in their own land: Maasai and wildlife conservation in Northern Tanzania. Conservation \& Society, 9, $65-79$.

Goldman, M.J. \& Milliary, S. (2014) From critique to engagement: re-evaluating the participatory model with Maasai in Northern Tanzania. Journal of Political Ecology, 21, 408-423.

Goldman, M.J. \& Riosmena, F. (2013) Adaptive capacity in Tanzanian Maasailand: changing strategies to cope with drought in fragmented landscapes. Global Environmental Change, 23, 588-597.

Gross-Camp, N.D., Martin, A., McGuire, S., Kebede, B. \& Munyarukaza, J. (2012) Payments for ecosystem services in an
African protected area: exploring issues of legitimacy, fairness, equity and effectiveness. Oryx, 46, 24-33.

Hayes, T., Murtinho, F., Camacho, L.M.C., Crespo, P., McHugh, S. \& Salmerón, D. (2015) Can conservation contracts co-exist with change? Payment for ecosystem services in the context of adaptive decision-making and sustainability. Environmental Management, $55,69-85$.

Horowitz, L.S. (2010) 'Twenty years is yesterday': science, multinational mining, and the political ecology of trust in New Caledonia. Geoforum, 41, 617-626.

Hulme, D. \& Murphree, M. (2001) African Wildife and Livelihoods: The Promise and Performance of Community Conservation. James Currey, Melton, UK.

Igoe, J. (2000) Ethnicity, civil society, and the Tanzanian pastoralist NGO movement: the continuities and discontinuities of liberalized development. $\mathrm{PhD}$ thesis. Boston University, Boston, USA.

I goe, J. (2004) Conservation and Globalization: A Study of National Parks and Indigenous Communities from East Africa to South Dakota. Wadsworth Cengage Learning, Belmont, USA.

Ingram, J.C., Wilkie, D., Clements, T., McNab, R.B., Nelson, F., BAUR, E.H. et al. (2014) Evidence of Payments for Ecosystem Services as a mechanism for supporting biodiversity conservation and rural livelihoods. Ecosystem Services, 7, 10-21.

Kahurananga, J. \& Silkiluwasha, F. (1997) The migration of zebra and wildebeest between Tarangire National Park and Simanjiro Plains, northern Tanzania, in 1972 and recent trends. African Journal of Ecology, 35, 179-185.

Kenya Wildife Service (KWS), The Wildiffe Foundation (TWF) \& Kitengela-Ilparakuo Land Owners Association (KILA) (2006) Proposed pastoralism and wildlife conservation zone for Isinya-Kitengela Master Plan 2006-2026 (Draft).

Kosoy, N. \& Corbera, E. (2010) Payments for ecosystem services as commodity fetishism. Ecological Economics, 69, 1228-1236.

Lawlor, K., Madeira, E.M., Blockhus, J. \& Ganz, D.J. (2013) Community participation and benefits in REDD+: a review of initial outcomes and lessons. Forests, 4, 296-318.

Matiko, D. (2014) Wildlife conservation leases are considerable conservation options outside protected areas: The KitengelaNairobi National Park Wildlife Conservation Lease Program. Journal of Ecosystem \& Ecography, 4, http://dx.doi.org/10.4172/ 2157-7625.1000146.

Milcu, A.I., Hanspach, J., Abson, D. \& Fischer, J. (2013) Cultural ecosystem services: a literature review and prospects for future research. Ecology and Society, 18, 44, http://dx.doi.org/10.5751/ ES-05790-180344.

Millennium Ecosystem Assessment (2005) Ecosystems and Human Well-Being: Synthesis Report. Island Press, Washington, DC, USA.

Msoffe, F.U., Kifugo, S.C., Said, M.Y., Neselle, M.O., Van Gardingen, P., Reid, R.S. et al. (2011) Drivers and impacts of land-use change in the Maasai Steppe of northern Tanzania: an ecological, social and political analysis. Journal of Land Use Science, 6, 261-281.

Muradian, R., Arsel, M., Pellegrini, L., Adaman, F., Aguilar, B., Agarwal, B. et al. (2013) Payments for ecosystem services and the fatal attraction of win-win solutions. Conservation Letters, 6 , 274-279.

Naidoo, R., Weaver, L.C., De Longcamp, M. \& Du Plessis, P. (2011) Namibia's community-based natural resource management programme: an unrecognized payments for ecosystem services scheme. Environmental Conservation, 38, 445-453.

Naughton-Treves, L. \& Wendland, K. (2014) Land tenure and tropical forest carbon management. World Development, 55 , $1-6$. 
Nelson, F., Foley, C., Foley, L.S., Leposo, A., Loure, E., Peterson, D. et al. (2010) Payments for ecosystem services as a framework for community-based conservation in Northern Tanzania. Conservation Biology, 24, 78-85.

Nkedianye, D., Radeny, M., Kristjanson, P. \& Herrero, M. (2009) Assessing returns to land and changing livelihood strategies in Kitengela. In Staying Maasai? Livelihoods, Conservation and Development in East African Rangelands (eds K. Homewood, P. Kristjanson \& P. Chenevix Trench), pp. 115-149. Springer Science + Business Media, New York, USA.

Oldekop, J.A., Holmes, G., Harris, W.E. \& Evans, K.L. (2016) A global assessment of the social and conservation outcomes of protected areas. Conservation Biology, 30, 133-141.

Pascual, U., Phelps, J., Garmendia, E., Brown, K., Corbera, E., Martin, A. et al. (2014) Social equity matters in payments for ecosystem services. BioScience, 64, 1027-1036.

Reid, R.S., Gichohi, H., Said, M.Y., Nkedianye, D., Ogutu, J.O., Kshatriya, M. et al. (2008) Fragmentation of a peri-urban savanna, Athi-Kaputiei Plains, Kenya. In Fragmentation in Semi-Arid and Arid Landscapes (eds K.A. Galvin, R.S. Reid, R. H. Behnke, Jr \& N. Thompson Hobbs), pp. 195-224. Springer, Dordrecht, The Netherlands.

Reid, R.S., Nkedianye, D., Said, M.Y., Kaelo, D., Neselle, M., MAKUi, O. et al. (2016) Evolution of models to support community and policy action with science: balancing pastoral livelihoods and wildlife conservation in savannas of East Africa. Proceedings of the National Academy of Sciences of the United States of America, 113, 4579-4584.

Sachedina, H. \& Nelson, F. (2010) Protected areas and community incentives in savannah ecosystems: a case study of Tanzania's Maasai Steppe. Oryx, 44, 390-398.

SACHEDINA, H.T. (2008) Wildlife is our oil: conservation, livelihoods and NGOs in the Tarangire Ecosystem, Tanzania. PhD thesis. University of Oxford, UK.

Salerno, J., Mulder, M.B., Grote, M.N., Ghiselli, M. \& Packer, C. (2016) Household livelihoods and conflict with wildlife in community-based conservation areas across northern Tanzania. Oryx, 50, 702-712.

Schröter, M., van der Zanden, E.H., van Oudenhoven, A.P.E., Remme, R.P., Serna-Chavez, H.M., De Groot, R.S. \&
Opdam, P. (2014) Ecosystem services as a contested concept: a synthesis of critique and counter-arguments. Conservation Letters, 7, 514-523.

Shapiro-Garza, E. (2013) Contesting the market-based nature of Mexico's national payments for ecosystem services programs: four sites of articulation and hybridization. Geoforum, 46, 5-15.

Sommerville, M., Jones, J.P.G., Rahajaharison, M. \& Milner-Gulland, E.J. (2010) The role of fairness and benefit distribution in community-based Payment for Environmental Services interventions: a case study from Menabe, Madagascar. Ecological Economics, 69, 1262-1271.

TLCT (Tanzanian Land Conservation Trust) (2002) The Manyara Ranch: A Reality Check. African Wildlife Foundation, Arusha, Tanzania.

Turnhout, E., Waterton, C., Neves, K. \& Buizer, M. (2013) Rethinking biodiversity: from goods and services to "living with". Conservation Letters, 6, 154-161.

Van Hecken, G., Bastiaensen, J. \& Windey, C. (2015) Towards a power-sensitive and socially informed analysis of payments for ecosystem services (PES): addressing the gaps in the current debate. Ecological Economics, 120, 117-125.

Waylen, K.A., Fischer, A., McGowan, P.J.K., Thirgood, S.J. \& Milner-Gulland, E.J. (2010) Effect of local cultural context on the success of community-based conservation interventions. Conservation Biology, 24, 1119-1129.

Wegner, G.I. (2016) Payments for ecosystem services (PES): a flexible, participatory, and integrated approach for improved conservation and equity outcomes. Environment, Development and Sustainability, 18, 617-644.

Wunder, S. (2013) When payments for environmental services will work for conservation. Conservation Letters, 6, 230-237.

\section{Biographical sketches}

Alici a DAVIs specializes in issues related to the environment, conservation, gender, health and zoonotic disease, and livelihoods in East Africa. Mara Goldman works with Maasai in Tanzania and Kenya on political ecology of conservation and development. 